\title{
Evolutionism and the Teaching of Science: How Portugal Has Been "Playing with the Big Tree of Evolution"
}

\author{
Sandra Assis • Susana Carvalho
}

Published online: 29 August 2012

(C) Springer Science+Business Media, LLC 2012

\begin{abstract}
The concept of evolution is fundamental to the teaching of biological sciences. Nevertheless, it seems frequently neglected and/or forgotten in our classrooms and absent from the school syllabus. These difficulties are present today in the Portuguese educational system, especially concerning the issue of human evolution. To overcome this difficulty, a multidisciplinary pilot project entitled Playing with the Big Tree of Evolution was developed by a nonprofit association called Group of Studies in Human Evolution in Portuguese schools and in other public and private organizations. Combining non-formal and informal apprenticeship, the project is composed of a set of pedagogical and experimental activities that aim to promote the broad concept of human evolution as well as to demystify
\end{abstract}

This paper was supported by Fundação para a Ciência e Tecnologia, Portugal [grant reference: SFRH/BD/36739/2007, Sandra Assis].

\section{S. Assis $\cdot$ S. Carvalho}

CIAS-Research Centre for Anthropology and Health,

Department of Life Sciences, University of Coimbra,

Coimbra, Portugal

S. Carvalho

Leverhulme Centre for Human Evolutionary Studies,

Department of Archaeology and Anthropology,

Division of Biological Anthropology, University of Cambridge,

Cambridge CB2 1QH, UK

S. Assis $\cdot$ S. Carvalho

GEEvH-Grupo de Estudos em Evolução Humana,

Department of Life Sciences, University of Coimbra,

Coimbra, Portugal

\section{S. Assis $(\bowtie)$}

CIAS-Centro de Investigação em Antropologia e Saúde, Departamento de Ciências da Vida, Faculdade de Ciências

e Tecnologia, Universidade de Coimbra,

Apartado 3046,

3001-401, Coimbra, Portugal

e-mail: sandraassis78@yahoo.com the anthropocentric perspective that places humans at the top of the chain of life.

Keywords Evolutionism - Non-formal and informal learning · Pedagogical activities · GEEvH (Group of Studies in Human Evolution) · Portugal

\section{Introduction}

Since time immemorial, humans have questioned their origin and cosmological place in the universe (Mayr 2001; Cela-Conde and Ayala 2007). The first explanations about life's diversity and the emergence of humanity relied on the driving force of elements or were attributed to supernatural entities (Lewin 1993; Mayr 2001, 2004; Wood 2005; Jurmain et al. 2009; Nickels 2010). Only in the nineteenth century, after the publication of the book On the Origin of Species by Natural Selection by Charles Darwin in 1859, did this scenario begin to be demystified (Lewin and Foley 2004). According to the new theory, all living forms are not immutable throughout time, but the result of a long evolutionary process constantly regulated by natural selection (Mayr 2004); in the case of modern humans, a journey that started probably five to eight million years ago (Wood 2005; Jurmain et al. 2009).

Human origins and evolution can be portrayed as a shifting puzzle, remarkably fascinating but far from being complete. In the challenging goal of reconstructing our evolutionary past, the recent fossil discoveries as well as the introduction of new tools of research, have played a major role. For example, we can point to the new ancestor candidate of the genus Homo, the Australopithecus sediba discovered in 2010 in South Africa (Berger et al. 2010). Composed of two partial skeletons, this new species aged 1.95 to 1.78 million years, displays a mosaic of craniodental and postcranial features that makes it a possible descendent 
of Australopithecus africanus and the best candidate for the early Homo ancestors (Berger et al. 2010; Carlson et al. 2010; Pickering et al. 2010; Kibii et al. 2010; Kivell et al. 2010; Zipfel et al. 2010). In 2008, the extraction of ancient mtDNA from a finger bone found in southern Siberia (Denisova Cave) also revealed unexpected results since it allowed the identification of a new archaic hominin 1.9 million years old (Krause et al. 2010; Reich et al. 2010). The genetic mapping of the phalange and its comparison with Neanderthal and modern human mtDNAs led to the conclusion that the Denisova individual shared a common ancestor with Neanderthals and anatomically modern humans but possesses a distinct evolutionary history, thus representing a new hominin form (Krause et al. 2010; Reich et al. 2010).

The concept of evolution is fundamental in the teaching of biological sciences in a way that goes beyond scientific explanations (Rudolph and Stewart 1998; Kennedy et al. 2004; Nickels 2010). According to Kennedy et al. (2004, p. 3 ): "biological evolution accounts for three of the most fundamental features of the world around us: the similarities among living things, the diversity of life, and many features of the physical world we inhabit." Thus, teaching biology without mentioning evolution deprives students of an important concept that brings order to our knowledge of life (Kennedy et al. 2004). Although the role of evolution is unquestionable, it frequently seems neglected and/or forgotten in the classrooms and by our students (Coalition of Scientific Societies 2008; Smith 2010). Ideological and religious views or simple unawareness are the main reasons for it (Coalition of Scientific Societies 2008). In addition, the old-fashioned textbook-based approach (Bloom 2006); the lack of updated books; and the discretionary relevance given to the subject can also contribute to intensifying the problem. These difficulties are present in the Portuguese educational system, especially in regard to the issue of teaching human evolution. To help in overcoming this difficulty, a multidisciplinary pilot project entitled Playing with the Big Tree of Evolution [Brincar com a Grande Árvore da Evolução] was developed and implemented in Portuguese schools, museums, and in other public and private institutions. Thus the aims of this paper are twofold: first, to outline the current situation concerning the teaching of evolution in Portugal and second, to present the project, describing the main activities and achievements following five years of execution.

\section{Teaching Evolution in Portugal}

The teaching of evolution is considered vital in the scholarly learning processes (Almaça 1999). According to Jenkins (2009), the natural sciences must be permeable to evolutionary theories since evolution is the key concept to understanding the living world. The theory of evolution can be portrayed as the aggregating factor of scientific instruction (Smith 2010; Yetişir and Kahyaoğlu 2005), allowing educators to differentiate science from other forms of human thought (National Academy of Sciences 1998). Evolutionary theory underscores the truly interdisciplinary face of science; furthermore, it offers a group of tools that enables students to explore the surrounding environments, and leads alumni to think about fundamental questions: "why things are the way they are currently and how they came to be that way" (Jenkins 2009, p. 347). However, throughout time, we have witnessed a decrease of interest in this central topic of natural sciences in the Portuguese school curriculum (Bracinha Vieira 2009). A quick survey of the web site of the Portuguese Ministry of Education and Science [available at: http://www.portugal.gov.pt/pt/os-ministerios/ministerio-daeducacao-e-ciencia.aspx], namely at the Direção Geral de Inovação e de Desenvolvimento Curricular [available at: http://www.dgidc.min-edu.pt/index.php] reveals that evolution, evolutionism, and generic Darwin's theory are topics that presently have an almost residual weight in the syllabus. In the particular case of human evolution, there was a reverse, comparing the current curriculum with the ones taught during the 1990s. At that time, the appearance of the first hominins, their main characteristics, habitats, and the origin of technologies were taught in the first year of secondary school as part of the history program. Today, the governmental program recommends: "a simplified analysis of the history of humanity. A circumscriptive study of the most fundamental moments is proposed, without analysis of the evolutionary process per se. This decision is motivated by factors linked with the psychological development of students and as a measure of economy of time in the class timescale" (Ministério da Educação 2009, p. 15). Furthermore, teachers are advised to focus on the social, technological, and economic transformations that occurred throughout the history of humankind instead of focusing on the biological changes that took place during human evolution (Ministério da Educação 2009). A simple overview of evolutionary principles related to the Earth's history is also recommended in the first year of secondary school in the class of life sciences (Galvão et al. 2001). At the end of secondary school, evolution returns as content in the classes of biology/geology as part of the sciences and technology program. Again, differences are found compared to the former Portuguese programs. For example, in the curricular year of 1995/1996, the subject of evolution was optional and taught in the beginning of the course. In the current program, it is relegated to the penultimate unit of the year syllabus and starts with a sentence that can be misleading: "There is no agreement about the forces that are responsible for biological diversity" (Mendes et al. 2004, p. 11). 
Additionally, teachers are advised that deep analysis of evolution theories should be avoided (Mendes et al. 2003).

Despite the "public" acceptance of Darwin's theory, Portuguese scientists say the acceptance it is only superficial (Bracinha Vieira 2009). Several reasons may explain the current situation: (1) naive interpretations of evolution; (2) ideological and religious views or simple unawareness; (3) old-fashioned textbook-based approach; (4) lack of updating concerning the newest discoveries; and (5) optional nature of this topic in biology classes (Bracinha Vieira 2009; Smith 2010). Other factors seem to reside in the apparent cleavage between the scientific community and ensuing knowledge produced in universities and research centers and the schools and/or general public. Accordingly, an interface between scientists and public is needed, which may be achieved by the introduction of informal and non-formal routes of science apprenticeship.

\section{The Portuguese project Playing with the Big Tree of Evolution: Description and Main Achievements}

Considering all the difficulties faced by Portuguese instructors in teaching evolution, as well as the interdisciplinary background required to do it, a nonprofit scientific organization called Group of Studies in Human Evolution (GEEvH) [http:// geevh.jimdo.com/] was created in 2005 by a group of students using the Master Course in Human Evolution (class 20042006) syllabus from the former Department of Anthropology at the University of Coimbra, Portugal. One of the main goals of the association is the scientific and pedagogical promotion of studies in Human Evolution. To fulfill this goal, efforts were made to disseminate Darwin's theory in schools, museums and among the general public by focusing on distinct disciplines since Darwin was himself an interdisciplinary thinker who consistently bridged geology, botanic, zoology, paleontology, embryology, ethology, and evolutionary systems in his theory (Bracinha Vieira 2009). As a result, a voluntary and multidisciplinary project centered on the topic of human evolution was developed in 2005 by the GEEvH. The project, entitled Playing with the Big Tree of Evolution was created within the scope of a national program called Ciencia Viva VI from the former Ministry of Science, Technology and High Degree, embracing a non-formal and informal apprenticeship. The project was composed of a set of pedagogical and experimental workshops that aimed to promote the broad concept of human evolution as well as to demystify the anthropocentric perspective that places humans at the top of the chain of life, embracing the idea that evolution is not a straight road but is a casual and unexpected event that needs constant updates.

Three major scientific branches determinant in the study of human evolution were targeted in these workshops, namely: biology, biological anthropology and its respective sub-divisions (e.g., paleoanthropology, human osteology, and primatology) and archaeology (Table 1). Each workshop was composed of a short theoretical presentation that aimed to introduce the main concepts in discussion, which was followed by practical and interactive activities. These activities were designed as hands-on experiments and/or informal games in which the students were asked to apply the concepts learned. For example, in workshop four, students were challenged to reproduce termite-fishing and nutcracking as it is done by our close relatives, the chimpanzees in nature. Despite the apparent simplicity, it is quickly recognized that these activities require a set of functional skills that range from the selection of the best raw material (e.g., the size and shape of the anvil and hammer stones), to good motor coordination for executing the task. In workshop five, students are invited to prepare natural pigments similar to those used by our ancestors for skin decoration and cave painting. Recreating a "prehistory chemistry lab," students learn how to produce pigments by crushing and grinding natural minerals, such as ochre (red or yellow oxides or hydroxides of iron) and charcoal, and to blend it with animal fat or egg white binders to obtain the same consistency as the oil paint and egg tempera used today. After the preparation of the pigments, they can start painting using handmade paintbrushes or simply their hands and imagination. Contrarily, the practical activity of workshop three was developed as a giant human roll-and-move game composed of questions about the biology and anatomy of the human skeleton. To play this game, two teams are formed at the beginning of the workshop, each of which will be responsible for the selection of four members: one to take notes during the presentation, a second to roll the dice, a third to move in the game as a "human pawn"; and a fourth to answer the questions, helped by the team colleagues. This measure aims to stimulate the division of tasks and cooperation between individuals all through the game. The rules of the game are simple: Each team rolls a die and moves the number of squares it shows. Some squares have questions and a bonus; others are in blank or have penalties. If a team answers a question correctly or moves to a bonus square, the pawn shifts automatically to the next square. If a wrong answer is given or a penalty square is reached, the pawn retreats one square. If a blank square is reached, the pawn remains in the same place. The team that finishes the game first wins. As a reward for good performance, both teams have the opportunity to reproduce an archaeological and anthropological excavation in a sandbox, recovering artifacts and bone casts (Figs. 1, 2, 3, 4, and 5).

The project was coordinated by researchers (volunteers) from the social and natural sciences and intended to be a scientific vehicle accessible to all students. By developing workshops and activities in non-formal and informal ways, 
Table 1 Descriptive summary of some of the activities developed during the project Playing with the Big Tree of Evolution

Workshop 1: "Evolution: at the first we were one ..."

Goal: to address the wonderful and still-unfolding story which started with the origin of the Universe.

Keypoints focused on: Big Bang and the origin of the Universe; the formation of the planet Earth and the origin of the first life forms; theories for the origin and diversity of life: Creationism vs. Evolution; Evolutionism and the role of the fossil evidence; introduction to the kingdoms of life,

Pedagogical activities: Game 1, The little naturalist: children will attempt to regroup several organisms, previously drawn and colored on paperboard, in kingdoms. Game 2, Let's play fossils...: fossils will be made in plaster simulating ammonites and trilobites and painted by children (Fig. 1).

Workshop 2: "Fossils: our grandparents"

Goals: to understand the evolutionary process through phylogenetic information derived from our closest relatives-primates-and fossils; to understand human origins and our ancestors, their main characteristics, habitats, and evolutionary adaptations.

Keypoints focused on: What are fossils and how are they formed? How do we understand human evolution? Inferences based on the study of nonhuman primates (phylogeny and taxonomy) and hominin fossil remains. Us and our closest relatives: locomotion, encephalization, tool use, and language.

Pedagogical activities: Game 1, From Pan to Homo: The game aims to consolidate knowledge about the main steps of human evolution. The game comprises a physical activity circuit and questions related to the oral presentation (Fig. 2). Game 2, Human Evolution Jeopardy Quiz: This interactive quiz is composed of several questions about the human evolution journey and is played by two distinct teams formed at the beginning of the workshop.

Workshop 3: "Dance of the skeletons"

Goals: To introduce the role of the skeleton in the physiological balance of the human body; to clarify the importance of recovering human skeletal remains from archaeological contexts to reconstruct past populations' history and evolution.

Keypoints focused on: basic notions of human osteology: What is the skeleton? What are bones made of? How does the human skeleton develop during fetal life? How many bones do children and adults have? What are the main function of the skeleton and joints? Short introduction to the work of the biological anthropologist in the field, during the recovery of the skeletal remains, and in the laboratory, focusing on the type of information that can be retrieved from ancient bones (e.g., sex and age at death of the individuals, ancestrality, diseases, diet, among others).

Pedagogical activities: Game 1, Bone's Dance: roll-and-move game comprised of several questions that finishes in the simulation of an excavation in a sandbox (Fig. 3).

Workshop 4: "Monkey business"

Goals: To present the taxonomic classification of the Order Primates; to introduce our closest living relatives; to reveal the importance of knowing nonhuman primates and the need to preserve their habitat.

Keypoints focused on: All are primates, but only some are monkeys: nomenclature and taxonomy of Primates. Our closest relatives: phylogeny of chimpanzees and humans, main differences, and similarities. What is the importance of studying the behavior of nonhuman primates? The importance of preserving habitats and their inhabitants.

Pedagogical activities: Game 1: Can you do it like they do?: The game intends to recreate some tool-use behaviors observed in wild chimpanzees, like termite-fishing and nut-cracking (Fig. 4).

Workshop 5: "Drawings and scribbles-Prehistoric art"

Goals: The concept of Art is applied to demonstrate prehistory's symbolic and social behavior. Being conceived as a "spirit transcends nature," art expresses itself by creating works with goals other than the satisfaction of subsistence needs. Art allows aesthetic expression linked with symbolic and playful behaviors.

Keypoints focused on: Prehistoric art: An introduction; Paleolithic and Late Prehistoric "Art": Notion, concept, topics, and techniques.

Pedagogical activities: Game 1: Our hands on paint: preparation of pigments and tools for painting (Fig. 5).

these researchers proposed to introduce new topics and reach for knowledge in an entertaining way, not only among students but also among the general public that usually does not have access to this kind of scientific information. According to the educational level, there was always an attempt to adjust the complexity of the subjects by guiding the discourse and simplifying the explanations and workshops.

The pedagogical activities were developed between the years of 2005 and 2009 in public and private schools, as well as in museums and scientific exhibitions, reaching approximately a total of 1,678 students from different educational levels (Fig. 6) and an uncountable number of participants from the general public.
As shown in Fig. 6, the greater number of students who participated in the workshops were from primary schools $(n=$ 779), a value followed by those from secondary schools ( $n=$ 596). In the last case, students from the first and second years of secondary school made up a high percentage $(n=496)$. When the distribution of the individuals by time-interval was considered, two years can be highlighted: the years 2006 and 2009 (Fig. 7).

The year 2006 accounted for 19\% (314/1678) of the participants and coincided with the special involvement of the GEEvH in an exhibition about human evolution entitled "Habitants e habitats" [Inhabitants and habitats] organized by the municipality of Leiria. In the year of 2009, two major events garnered almost $63 \%(1,055 / 1,678)$ of the participants, namely, the event Sobre as pegadas do passado [Upon the 
Fig. 1 Evolution: at the first we were one...workshop.

Clockwise: introduction to some concepts about life origin, evolution, and diversity; preparation for the game "Let's play fossils"; example of the fossil casts used for painting; painting in action (photos courtesy: Câmara Municipal de Leiria)
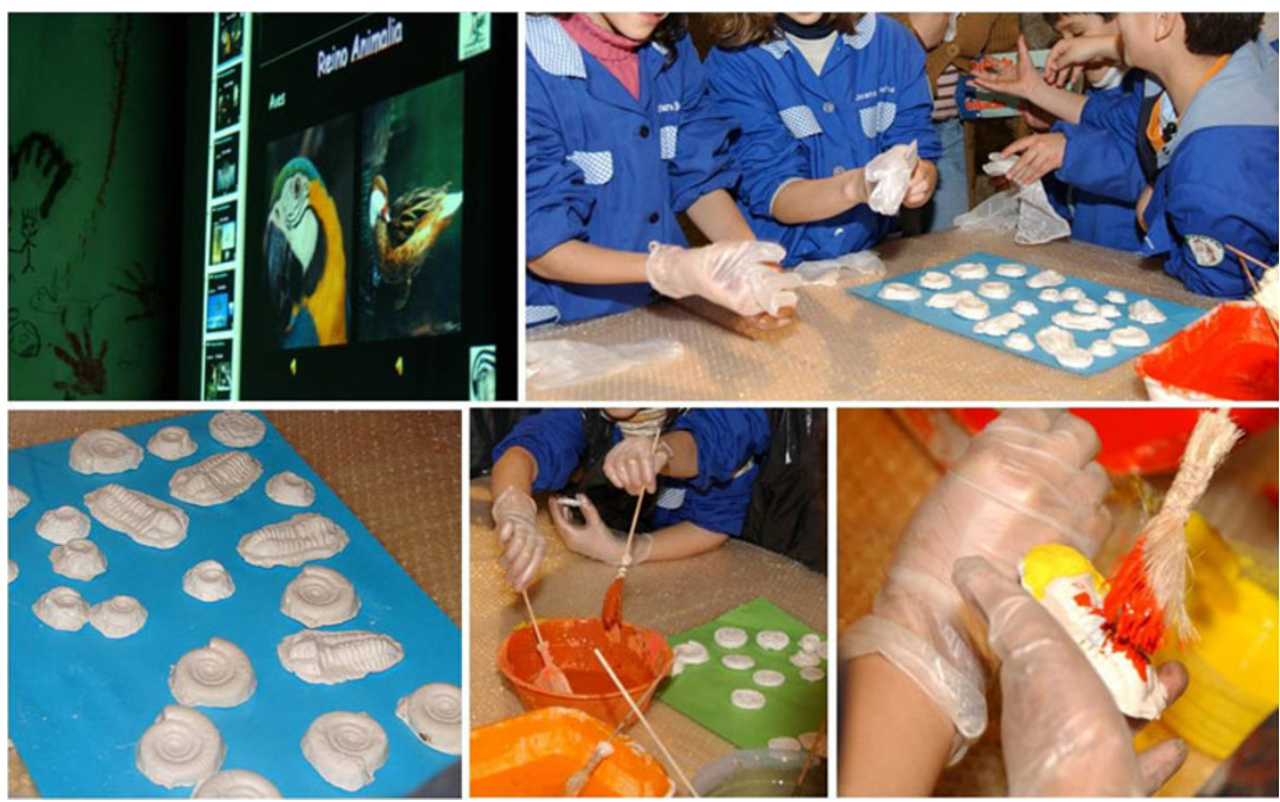

past footsteps] promoted by the former Anthropological Museum - Museum of Natural History from the University of Coimbra - and the pedagogical activities that took place at the Museum D. Diogo de Sousa in the city of Braga, Northern of Portugal. Both events had the partnership and support of the Research Centre for Anthropology and Health at the University of Coimbra. From the 18 administrative districts of continental Portugal, six were covered by the project, such as Braga and Guarda (in the north); Viseu, Coimbra and Leiria (in central Portugal), and Lisbon (in the south). During the implementation of the project, the following were observed: (1) great interactivity, not only during the presentation, but also when the students were asked to apply the acquired knowledge in practical activities; (2) fast acquisition of concepts and theories; (3) interconnection between the new and the previous knowledge; and (4) a much larger demand than the possible supplied workshops: Most of the institutions targeted by these activities expressed their will to have access to more workshops, which was not always possible due to the volunteer nature of this work. Furthermore, the pedagogical
Fig. 2 Fossils: our grandparent's workshop. Clockwise: exhibition of some concepts about human evolution; fossil casts of our ancestors; steps of the game "From Pan to Homo" (photos courtesy: Câmara Municipal de Leiria)
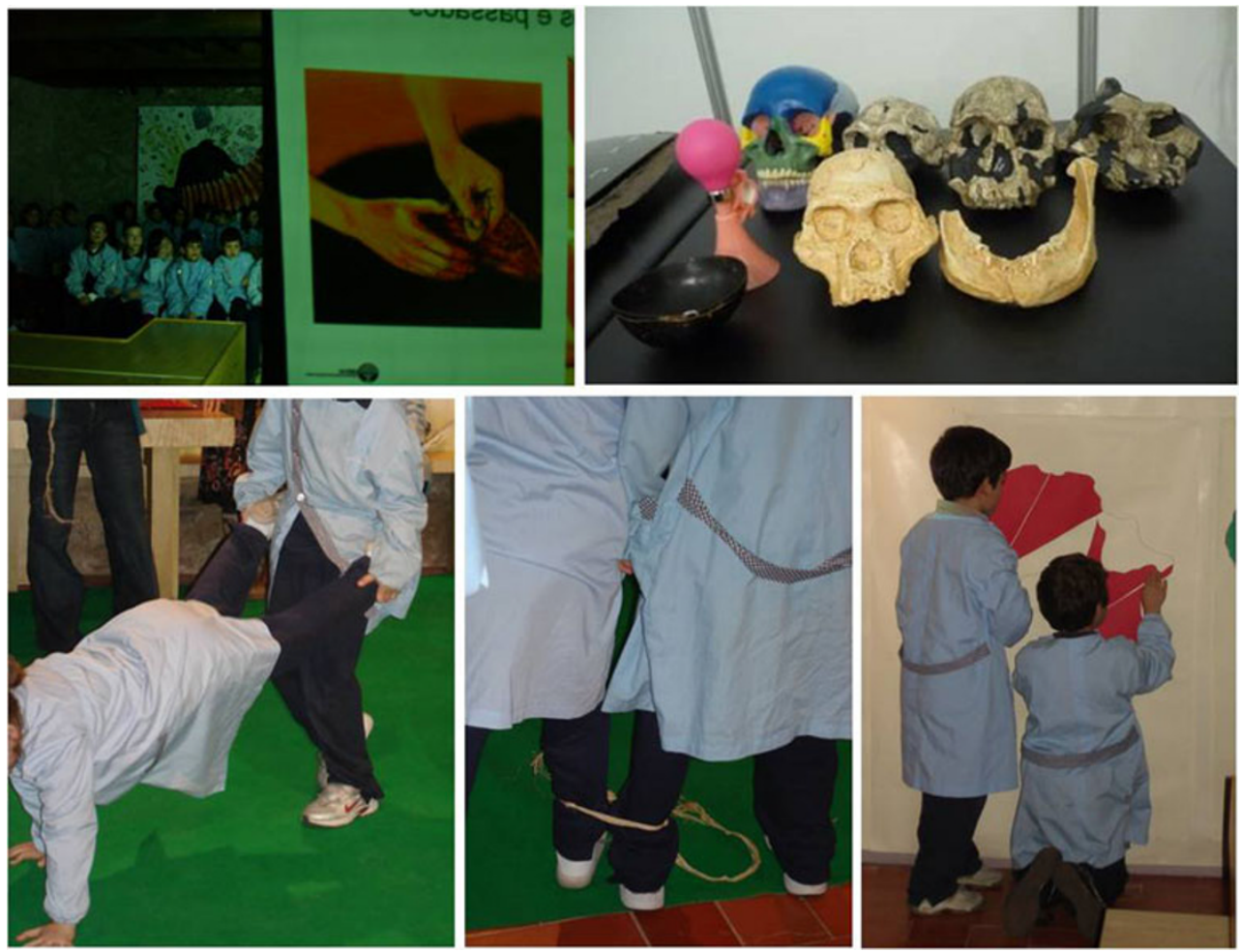
Fig. 3 Dance of the skeletons workshop. Clockwise: introduction of the main theoretical concepts; quiz game; reproduction of an archeological/anthropological excavation at a sandbox; and the chief inspiration, the human skeleton (photos courtesy: Câmara Municipal de Leiria)
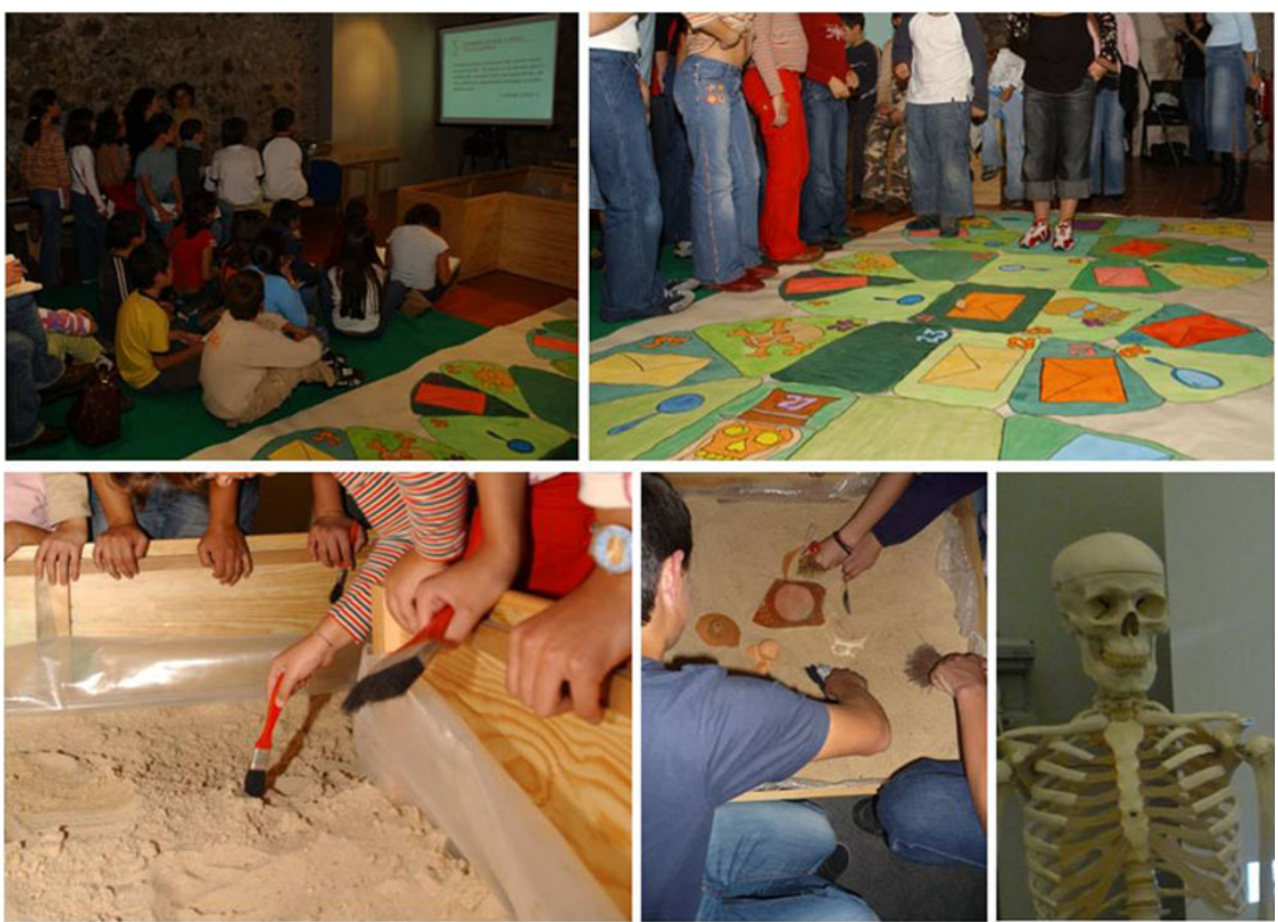

nature of these activities was viewed by teachers and educators as a good complement to their formal school programs. Activities that need further restructuring are those directed to the public with special needs, namely in the adequacy of the discourse.

\section{Final Remarks}

Scientific research, especially that devoted to the study of human evolution, is one of the most active fields that is in constant mutation in biology (Kennedy et al. 2004). This reality makes the teacher's work more complex. Although an irreplaceable role is played by the official school in education, there are other opportunities beyond the textbook approach using non-formal and informal apprenticeships in science created by distinct institutions such as the media, science centers and museums, industry-education programs, out-of-school programs, and community educational initiatives (Honeyman 1998; Bloom 2006). This wider approach inspired the creation of the project Playing with the Big Tree of Evolution as a novel route of promoting human
Fig. 4 Monkey business workshop. Clockwise: presentation of some topics concerning the taxonomy and nomenclature of primates, as well as about the phylogeny of chimpanzees and humans; steps of the game "Can you do it like they do?" that intended to recreate some tool-use behaviors observed in wild chimpanzees, like termite-fishing and nutcracking (photos courtesy: Câmara Municipal de Leiria)
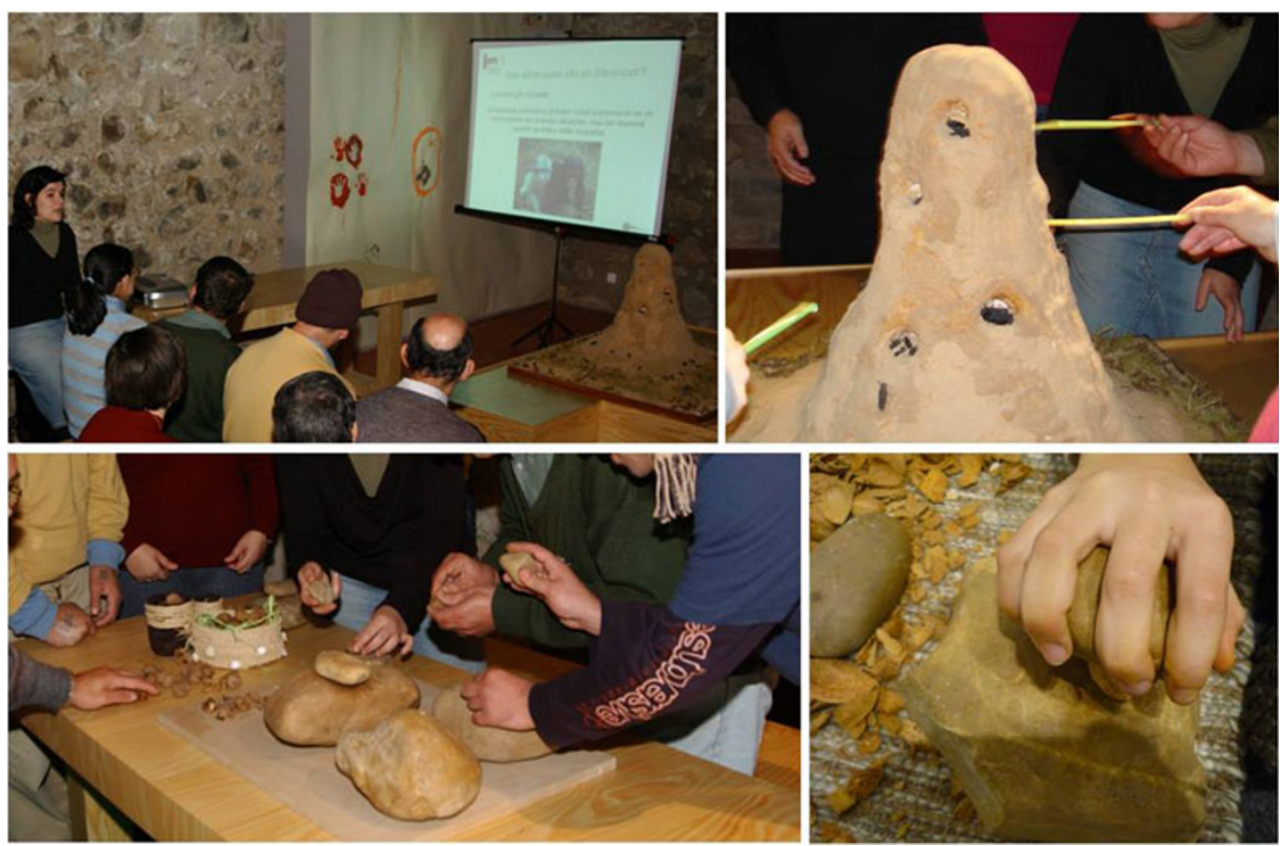
Fig. 5 Drawings and scribbles - Prehistoric art workshop. Clockwise: theoretical presentation about Prehistoric art, namely definition and types of natural pigments used to produce ink; natural brushes and substances to paint; children painting and their works (photos courtesy: Câmara Municipal de Leiria)

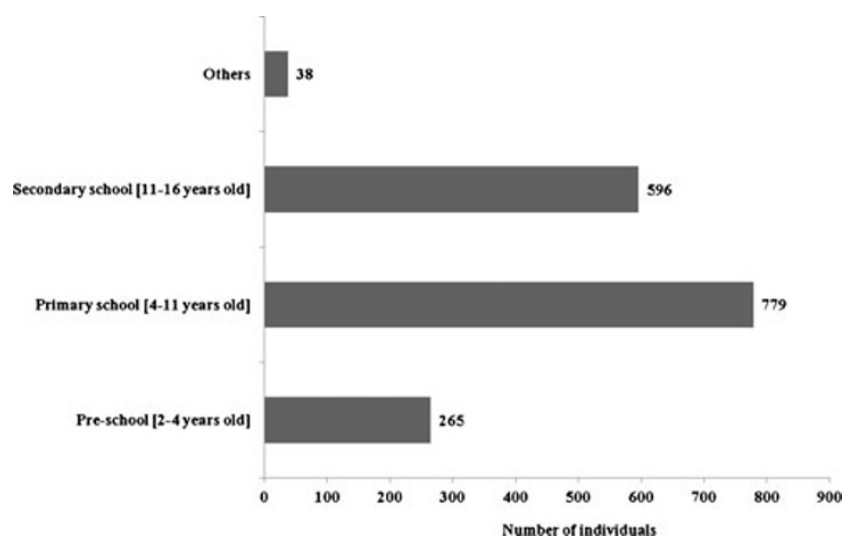

Fig. 6 Distribution of individuals by educational level

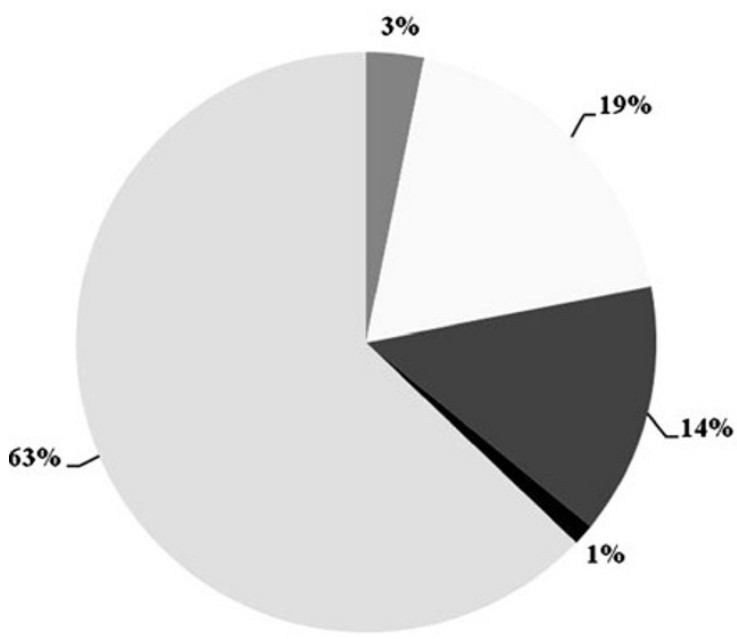

$=2005$

Fig. 7 Distribution of individuals by years of the project

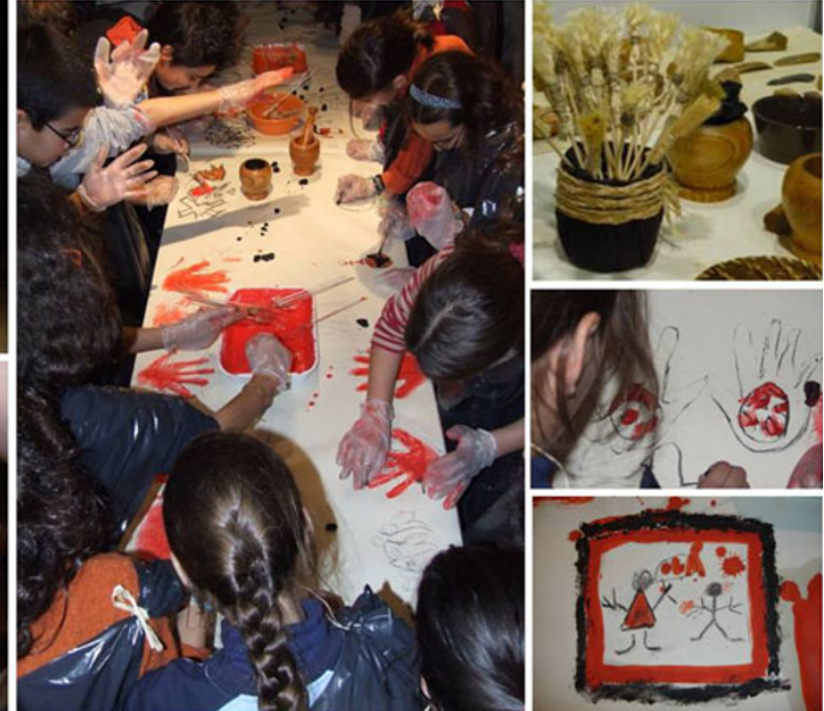

evolutionary studies in schools and among the general public. After five years of activity, it is possible to conclude that this type of approach is well accepted by the community, constituting an optimal complement to the formal teaching; one that can be easily be adapted to other fields of biology and life sciences. Focusing on the Portuguese case, one feels that more initiatives need to be developed in similar areas in order to fill the gaps that may exist in school programs, and foremost, to spread the message that: Science is not grey; on the contrary, it is colorful and fun!

Acknowledgments We would like to thank the Office of the Board of the Grupo de Estudos em Evolução Humana, associates, school and museum staff, teachers, students, volunteers, and monitors that have participated in the workshops; CIAS-Research Centre for Anthropology and Health from the University of Coimbra, Municipality of Leiria, and Museu D. Diogo de Sousa (Braga) for all the material support. Special thanks go to Dra. Maria Arminda Miranda. The acquisition of supplies was funded by the Ciência Viva VI, former Ministry of Science, Technology and High Degree, code reference CV/PVI 1845.

\section{References}

Almaça C. O Darwinismo na Universidade portuguesa (1865-1890). Lisboa: Museu Bocage, Museu Nacional de História Natural; 1999.

Berger LR, Ruiter D, Churchill S, Schmid P, Carlson L, Dirks P, et al. Australopithecus sediba: a new species of Homo-like Australopith from South Africa. Science. 2010;328(5975):195-204.

Bloom J. Creating a classroom community of young scientists. New York: Routledge; 2006.

Bracinha Vieira A. A evolução do Darwinismo. Lisboa: Edições Fim de Século; 2009.

Carlson K, Stout D, Jashashvili T, Ruiter D, Tafforeau P, Carlson K, et al. The endocast of MH1, Australopithecus sediba. Science. 2010;333(6048):1402-7.

Cela-Conde C, Ayala F. Human evolution: trails from the past. Oxford: Oxford University Press; 2007. 
Coalition of Scientific Societies. From the society for developmental biology: you say you want an evolution? A role for scientists in science education. Dev Biol. 2008;316:2-5.

Galvão C, Neves A, Freire AM, Lopes AM, Santos M, Vilela M, et al. Orientações Curriculares: Ciências Físicas e Naturais ( $3^{\circ}$ Ciclo). Lisboa: Ministério da Educação, Departamento da Educação Básica. http://sitio.dgidc.min-edu.pt/basico/Paginas/default.aspx (2001).

Honeyman B. Non-formal and formal learning interactions: new directions for scientific and technological literacy. Connect-UNESCO International Science. Technol Environ Educ Newsl. 1998;23 (1):1-16.

Jenkins K. Evolution in biology education: sparking imaginations and supporting learning. Evol Educ Outreach. 2009;2:347-8.

Jurmain R, Kilgore L, Trevathan W. Essentials of physical anthropology. Belmont: Wadsworth Cengage Learning; 2009.

Kennedy D, Alberts B, Ezell D, Goldsmith T, Hazen R, Lederman N, et al. Teaching about evolution and the nature of science. Washington: National Academic Press; 2004.

Kibii J, Churchill S, Schmid P, Carlson K, Reed N, Ruiter D, et al. A partial pelvis of Australopithecus sediba. Science. 2010;333 (6048):1407-11.

Kivell T, Kibii J, Churchill S, Schmid P, Berger L. Australopithecus sediba hand demonstrates mosaic evolution of locomotor and manipulative abilities. Science. 2010;333(6048):1411-7.

Krause J, Fu Q, Good J, Viola B, Shunkov M, Derevianko A, et al. The complete mitochondrial DNA genome of an unknown hominin from southern Siberia. Nature. 2010;464:894-7.

Lewin R. The origin of modern humans. New York: Scientific American Library; 1993.

Lewin R, Foley R. Principles of human evolution. Malden: Blackwell Publishing Ltd; 2004.

Mayr E. What evolution is. London: Phoenix Paperback; 2001.

Mayr E. What makes biology unique? Considerations on the autonomy of a scientific discipline. Cambridge: Cambridge University Press; 2004.
Mendes A, Rebelo D, Pinheiro E, Silva C, Amador F, Baptista J, et al. Programa de Biologia e Geologia $\left(11^{\circ}\right.$ ou $12^{\circ}$ anos): curso Científico-Humanístico de Ciências e Tecnologias. Lisboa: Ministério da Educação, Direcção-Geral de Inovação e de Desenvolvimento Curricular. http://www.dgidc.min-edu.pt/ensinosecundario/index.php? $\mathrm{s}=$ directorio\&pid $=2$ (2004).

Ministério da Educação. Programa História: Plano de organização do ensino-aprendizagem (Ensino básico, $3^{\circ}$ Ciclo). Vol. II. Lisboa: Direcção Geral dos Ensinos Básico e Secundário. http://sitio.dgidc. min-edu.pt/secundario/Paginas/Progr orient curricSEC.aspx (2009).

National Academy of Sciences. Teaching about evolution and the nature of science. Washington, DC: National Academies Press; 1998.

Nickels M. Science education and physical anthropology. In: Larsen CS, editor. A companion to biological anthropology. Malden: Blackwell Publishing Ltd; 2010. p. 547-60.

Pickering R, Dirks P, Jinnah Z, Ruiter D, Churchill S, Herries A, et al. Australopithecus sediba at $1.977 \mathrm{Ma}$ and implications of the origin of genus Homo. Science. 2010;333(6048):1421-3.

Reich D, Green R, Kircher M, Krause J, Patterson N, Durand E, et al. Genetic history of an archaic hominin group from Denisova Cave in Siberia. Nature. 2010;468:1053-60.

Rudolph J, Stewart J. Evolution and the nature of science: on the historical discord and its implications for education. J Res Sci Teach. 1998;35(10):1069-89.

Smith M. Current status of research in teaching and learning evolution: I. Philosophical/epistemological issues. Sci Educ. 2010;19(68):523-38.

Wood B. Human evolution: a short introduction. Oxford: Oxford University Press; 2005

Yetişir M, Kahyaoğlu M. 2010. Pre-service teachers' attitudes towards teaching of evolution theory. Procedia Soc Behav Sci. 2005; 2:1720-2724.

Zipfel B, DeSilva J, Kidd R, Carlson K, Churchill S, Berger L. The foot and ankle of Australopithecus sediba. Science. 2010;333 (6048):1417-20. 